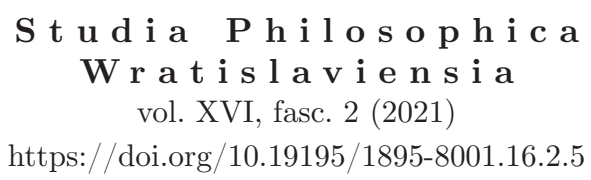

\author{
KAMILA GHEORGHE \\ ORCID: 0000-0003-0829-275X \\ Uniwersytet Śląski w Katowicach
}

\title{
Fernando Savater: philosopher-activist
}

\begin{abstract}
The article concerns the life and work of the most important contemporary Spanish philosophers, Fernando Savater. It focuses on describing his activism and the reasons which led him to participate in the public life. The author also analyses the thinker's two major concerns, which are anti-nationalism and the defence of democtratic values. The investigation shows that Savater's view on the two issues is strictly related to his biography and the socio-political changes experienced by Spanish people in the last fifty years. The solutions the philosopher presents for his compatriots are parallel to his proposals of shifts in the politics of the whole European Union.
\end{abstract}

Keywords: philosophy, Spanish philosophy, Savater, nationalism, terrorism, democracy

Nationality being an irrational accident, like sex or complexion, a man's allegiance to his country must be conditional, at least if he is a philosopher. His patriotism has to be subordinated to rational allegiance to such things as justice and humanity.

George Santayana Three Philosophical Poets: Lucretius, Dante, and Goethe

Fernando Savater is not only the most important contemporary philosophers of the Hispanic countries, but he is also a prominent public figure. He has always been engaged in the Spanish public discourse. He has played a key role in significant civic movements and inspired changes on the political stage in Spain. Both his activity and his thought keep raising criticism which revives the intellectual life of his homeland. 
He considers himself more of a teacher than a philosopher due to the fact that he was a university professor for nearly forty years. Not only does he perceive shaping young minds as crucial for a country's well-being, but he also seems to derive immense pleasure from doing so. Notwithstanding this fact, he proved himself to be a remarkable and popular writer. Moreover, his philosophical essays on ethics and politics go together with his civic attitude.

Savater was born in 1947 in the city of San Sebastián (the Basque Country). Both his place of birth as well as his family roots seem to determine the trajectory of his thought and activity. As he reveals in his biography, his father was originally Granadan, his mother was born in Madrid, while her mother - in Buenos Aires, and his great grandparents were Catalans. ${ }^{1}$ Given the circumstances, his ancestry may be one of the reasons which stand behind his cosmopolitanism. Apart from other qualities, the multiple identities his wife and former student, Sara Torres, had, made her Savater's perfect companion. Born in the Canary Islands, raised in Barcelona, Torres, who studied in the Basque Country, was able to speak Castilian, Catalan and Euskara fluently and shared her husband's curiosity of the world.

Still, the philosopher strongly objects to any suggestions denying his Basqueness. ${ }^{2}$ For not only was he born in San Sebastián and spent there his youth, but he was also an ethics professor at the recently founded University of the Basque Country in the 1980s and an active participant in the local public life. Undoubtedly, this experience is what made him the eager critic of nationalism he is still today.

Before that he worked at the Autonomous University of Madrid, however, he was removed from teaching for political reasons. For most of his academic career, he was employed by the Complutense University of Madrid. Fernando Savater is a retired professor, a philosopher, an author of nearly a hundred books. ${ }^{3} \mathrm{He}$ became a columnist for El País the very year the newspaper was founded and he gladly holds the position till this day.

Apart from his writings, he receoved international recognition for his activism. Due to his involvement in ¡Basta Ya! (Enough is Enough!) organization, which was opposing Basque terrorism, ETA sentenced him to death. In consequence, he was forced to be assisted by a security guard for a decade. Moreover, he was one of the founders of the political party UPyD (Unión, Progreso y Democracia - Union, Progress and Democracy).

Adam Michnik has a very warm relationship with Savater, and he maintains that his two most successful books (Ética para Amador and Política para Amador) should become a "catechism"4 for contemporary European citizens.

${ }^{1}$ Cf. F. Savater, Mira por dónde. Autobiografía razonada, Madrid 2003, p. 31. All translations done by the authoress of the article.

${ }^{2}$ He recalls a public discussion in the Basque Country to which he was invited together with Javier Sábada. When the listeners started to express their dissatisfaction with Savater's comments on Basque terrorism, Sábada appealed for "those from here' to respect 'those from outside"" (those who are not originally from the Basque Country). The statement made Savater not just offended but furious (ibidem, p. 378).

${ }^{3}$ Among them one may find also novels and plays.

${ }^{4}$ IE University, Hay Festival Segovia Fernando Savater y Adam Michnik. La lucha por Europa, 2020, https://www.youtube.com/watch?v=GYkAwRvF1Z0\&t=940s (accessed: 10.05.2021). 


\section{Philosophical legacy}

Fernando Savater wrote his $\mathrm{PhD}$ thesis on the thought of Emil Cioran, which was published in 1974 under the title Ensayo sobre Cioran. Recently, it was included in the book Todo mi Cioran, which contains additional writings on the Romanian philosopher as well as a letter Cioran sent to Savater commenting on his thesis. Cioran's pessimism and perspicacity have always been a great inspiration for his Spanish admirer. What is more, Savater became a translator of Cioran's books and a popularizer of his thought in Spain.

The two branches of philosophy to which the Basque thinker is primarily dedicated are ethics and political philosophy. The first period of his research (the 1970s) is an expression of negativism. In his first philosophical books, Savater mostly articulates which concept he rejects. In the 1980s, he develops his ethical proposals and as of the 1990s on, he focuses to a large extent on the defence of democratic values.

\section{Political philosophy}

Back in the 1970s and early 1980s Savater revealed himself as an anarchist in his work Para la anarquía y otros enfrentamientos and Panfleto contra el Todo. He was a harsh critic of the shape of Spanish university education and scientific discourse of the time (La filosofía tachada), a proponent of antimilitarism (Las razones del antimilitarismo y otras razones) and an objector to the state penitentiary system (Teoría y presencia de la tortura en España).

With the publication of Contra las patrias in 1984 Savater started his intellectual fight against nationalism, which he continues also nowadays. In 2017 he wrote Contra el separatismo expressing his preoccupation with the political situation in both Catalonia and the Basque Country.

The realisation of the dangers of so-called peripheral nationalism and the witnessing of the 1981's Tejero's coup d'état made the philosopher change his approach to the post-transitional political situation of his country. With time he became a passionate supporter of democracy and a determined defender of the unity of the Spanish state. The books that show best his commitment to democratic values are El valor de elegir or ;No te prives! Defensa de la ciudadanía among others.

\section{Ethics}

Savater has always shared the Aristotelian idea that ethics aims to make us live a good life. In his view, a "good life" is always "tailored" for a concrete human being and ethics is an art of tailoring.

In 1981 La tarea del héroe was published, a work that gave Savater a prize granted annually by the Spanish Ministry of Culture (Premio Nacional de En-

${ }^{5}$ Cf. F. Savater, Pensar la vida. Ética para Amador. Politica para Amador. Las preguntas de la vida, Barcelona 2016, p. 136. 
sayo). In this book, the idea of a tragic aspect of ethics is being developed together with the concept of "acknowledgement in the other, ${ }^{16}$ which one might associate with the philosophy of dialogue.

In Ética como amor propio the author aims to reclaim the validity of the ancient idea of egoism as a base for ethics, which led him to elaborate on related matters such as joy or happiness (El contenido de la felicidad). In Ética para la empresa he presents his views on business ethics.

\section{Education}

Becoming a supporter of democracy as well as working as a professor, Savater's attention was drawn to the topic of how education and democracy condition each other. He has always defended the idea of teaching ethics in high school, and he is a great enthusiast of the subject Educación para la Ciudadania (Education for Citizenship). He claims it is crucial to raise the young generation so that they become autonomous individuals who are able to examine critically the social reality, are willing to collaborate with other citizens and participate in public life. His main thoughts on education were formulated in the book El valor de educar, which had an especially significant impact in Latin America. ${ }^{7}$

\section{Popularization of philosophy and literature}

The most known Savater's book is a sort of ethics manual he wrote for his son. Ética para Amador was translated into many languages (including Polish ${ }^{8}$ ) and had several editions. In 2016 it was published together with Politica para Amador and Preguntas de la vida. ${ }^{9}$ The three books are considered high school reads on ethics, civic education and fundamental philosophical matters. They are very well structured and written in an accessible language. Every chapter is summed up by related questions followed by quotes from famous philosophers related to the topic in question.

Published in 2012, Ética de urgencia was thought of as a continuation of Ética para Amador adjusted to current issues the youth may face. It combines answers the philosopher gave to the questions raised by the students and their teachers to which they did not find direct solutions in the previous manual.

In La aventura del pensamiento Savater presents the thought of twenty-six philosophers starting with Plato and finishing with Michel Foucault. Historia de la filosofía sin temor ni temblor is a similar attempt. The Spanish thinker writes in it about the history of philosophy employing a dialogue between two characters - Nemo and Alba.

${ }^{6}$ F. Savater, La tarea del héroe, Barcelona 2004, p. 124.

${ }^{7}$ Cf. M. Nogueroles Jové, Fernando Savater. Biografía intelectual de un «joven filósofo», Madrid 2013, p. 322 .

${ }^{8}$ Cf. F. Savater, Etyka dla syna, transl. J. Wojcieszak, Warszawa 1996.

${ }^{9}$ Cf. F. Savater, Pensar la vida. 
Apart from the book dedicated to Cioran, Savater wrote a few more which focus on philosophers to make their thought more accessible for an average reader. Besides the ones on Plato ${ }^{10}$ and Nietzsche, ${ }^{11}$ the book for which Savater most probably has the deepest fondness is Voltaire contra los fanáticos. It is in a way a dictionary of Voltaire quotes organised thematically and alphabetically (from Abbé to Virtue). ${ }^{12}$ The French philosopher is a crucial inspiration for the author of Ética para Amador, especially when it comes to his concept of the secular country, tolerance and freedom.

What is more, Savater is a great erudite. Therefore, quite an amount of his work is dedicated to the popularisation of literature. His book on Jorge Luis Borges $^{13}$ is surely worth mentioning together with the publications in which he narrates biographical facts and places related to his favourite writers in Aqui viven leones written together with his wife. The readers can familiaris themselves with William Shakespeare, Agatha Christie, Edgar Allan Poe or the Spanish modernist Ramón María del Valle-Inclán among others. A similar idea underlies the short movies selection Lugares con genio published in a DVD format. Savater visits the cities in which iconic authors lived and created their memorable works. He takes the spectators for a tour through Dante's Florence, Virginia Woolf's London, Franz Kafka's Prague or Pablo Neruda's Santiago de Chile.

\section{ETA}

One of the decisive aspects of Spanish socio-political life which shaped Savater's political philosophy is undoubtedly his experience of living in the Basque Country and directly facing the activity of ETA. The name of this Basque terrorist organization - Euskadi Ta Askatasuna - may be translated as "Basque Homeland and Liberty". It was founded in 1959 and announced its final dissolution only in 2018. ${ }^{14}$ Up to 864 people were killed during ETA's activity. ${ }^{15}$

The first mortal victim was the Civil Guard officer, José Pardines who was killed only in 1968 since in the first years of ETA's activity the fight was more symbolic than brutal. They were devastating railway tracks, blowing up Francoist monuments or putting ikurriñas ${ }^{16}$ and making graffiti on public buildings using Euskara. Before the death of Franco (1975), ETA had quite a long list of sympa-

10 Cf. F. Savater, La escuela de Platón, Barcelona 1991.

11 Cf. F. Savater, La idea de Nietzsche, Barcelona 1995.

12 Cf. F. Savater, Voltaire contra los fanáticos, Barcelona 2015.

13 Cf. F. Savater, Jorge Luis Borges: la ironía metafísica, Barcelona 2000.

${ }^{14}$ Cf. M. Ormazabal, 'ETA anuncia su disolución,' El País 3.05.2018, https://elpais.com/politica/2018/05/03/actualidad/1525336524_523980.html (accessed: 10.05.2021). In 2010 a ceasefire was declared and in 2017 the organization was disarmed. The ceasefire announcement was widely criticised among Spanish citizens, including Savater himself, expecting the total dismantling of ETA structures and the end of their political activity.

${ }^{15}$ Cf. A. Escriva, 'El testamento de ETA: 864 asesinados "por amor",' El Mundo 28.04.2021, https://www.elmundo.es/cronica/2021/04/28/6082fd4cfc6c83651b8b45a3.html (accessed: 10.05.2021).

16 The Basque County's flag. 
thizers and some international support, as it was seen as an organization fighting a fascist dictatorship. However, after the democratic transition, the number of assassinations committed per year grew even five times compared to the last years of Franco's governance. ${ }^{17}$ The Bask Country gained the status of an autonomous region and the most favourable fiscal agreement with the central government yet the attacks were not stopping. With time more and more civilians, including women and children, were getting killed. The attacks reached out beyond the borders of the Bask Country too, hence the Spanish society started to protest.

\section{The experience of the University of the Basque Country}

In 1980 Savater was hired as an ethics professor in the recently founded University of the Basque Country. As the philosopher admits in his biography, at this point few lecturers were willing to work in academia as "the Basque Country was inspiring certain fear due to the situation of prevailing violence." 18 He did not hesitate to take the position as he had always dreamt of coming back to San Sebastián. What is more, he declares that he did not regret the decision as the years he spent teaching philosophy in his birthplace were "entertaining, turbulent and unpredictable: the best what one can ask for from life."19

At first, what was characteristic of the university was freedom and a great deal of equality in the relationship between the academic staff and the students. It did not take long for Savater to become one of the intellectual leaders. It was not elsewhere but in a classroom of the University of the Basque Country where he met his future wife. ${ }^{20}$

The first years of Savater lecturing in the Basque Country were the period during which his anti-nationalist views started to shape. Since he has always shown tendencies towards being a radical and provocative thinker engaged in the social reality, he kept expressing his criticism towards terrorism in ETA's cradle as well as in the Spanish capital. His implacable attitude was arousing more and more opposition among the Basque radicals and their supporters. When in 1987 the philosopher published an article in which he called ETA members torturers, the aggression towards him started to materialise. Regularly he was finding insults written or coffins drawn on the door of his university office. ${ }^{21}$

At the same time the freedom that ruled the university that he cherished so much started to crumble. Many of the professors were demonstrating appreciation for ETA and their political wing and Herri Batasuna wanted to have the univer-

17 Meanwhile in 1974 eighteen people were killed and in 1975 - sixteen, ninety-five were assassinated in 1980 only. It was the year with the highest number of ETA's fatal victims in the organization's whole history. Cf. M. Ceberio Belaza, 'El dolor por 854 muertos y miles de amenazados y heridos,' El País 4.05.2028, https://elpais.com/politica/2018/05/03/actualidad/1525374369_414522.html (accessed: 10.05.2021).

18 F. Savater, Mira por dónde, p. 356.

19 Ibidem, p. 357.

${ }^{20}$ As he reveals, many of the professors were marrying their former students. Cf. ibidem, p. 360 .

${ }^{21}$ Cf. ibidem, p. 372. 
sity under their control. "In this period the assassinations were being justified [...]. Neither the classes were being suspended nor the universities closed in an act of protest against the attacks and it was frequent that a hooded person was taking over professor's pulpit to read a communication," 22 Miguel Grijalba Uche describes the atmosphere dominating academic life in the Basque Country in the late 1980s.

Savater left his position in 1993 with his anti-nationalism well founded, as the return to his birthplace "woke him up and opened his eyes."23

\section{Activism}

Savater's engagement in civic movements started in 1977. The first issue he was preoccupied with was the situation and status of convicts in Spanish prisons. He participated actively in Movimiento de presos sociales durante la Transición, he was also a member of the governing board of Asociación para el Estudio de los Problemas de los Presos y Ex-presos (AEPPE). ${ }^{24}$ In addition, he became a member of Amnesty International. In this period his activism was clearly inspired by Michel's Foucault idea presented in the work Discipline and punish. The presentation of AEPPE stated that "The prison should stop being considered as something normal" 25 and that the prisoners' separation from society results in a total rescission of their humanity.

In the next decades, the philosopher played a key role in organizations fighting down ETA terrorism. He became a member of Movimiento por la Paz y no Violencia and Gesto por la Paz. ${ }^{26}$ The main aims of the latter were to promote the culture of peace, raise social awareness and mobilization against violence and fight terrorism by respecting democratic principles. After the assassination of the politician, Miguel Ángel Blanco, ${ }^{27}$ Savater was one of the founders of Foro Ermua. The organization focused on supporting the victims of terrorism, reporting the acts of terrorism as well as defending the Spanish Constitution and the Basque Statute of Autonomy.

Unquestionably though, the main accomplishment of the philosopher was his participation in the initiative ¡Basta Ya! as its spokesman. The organization was integrating the main ideas of the previously created movements. Preparation of demonstrations and acts of protest was its main activity. In 2000 ¡Basta Ya! was awarded the Sakharov Prize for Freedom of Thought "for its active campaigning

\footnotetext{
${ }^{22}$ M. Grijalba Uche, El laicismo en el pensamiento de Fernando Savater, 2016, http://e-spacio. uned.es/fez/eserv/tesisuned:Filosofia-Mgrijalba/GRIJALBA_UCHE_Miguel_Tesis.pdf, p. 75.

${ }^{23}$ Ibidem, p. 79.

${ }^{24}$ And others. Cf. M. Nogueroles Jové, Fernando Savater, p. 33-34.

${ }^{25}$ Ibidem, p. 144.

${ }^{26}$ Cf. ibidem, p. 32.

27 Miguel Ángel Blanco (1968-1997) was a councilor of the Basque city of Ermua on behalf of the People's Party who was kidnapped and brutally killed by ETA. The death of the young politician provoked a deep outrage of the public opinion. Large demonstrations were being organized during which people were raising hands with the palms painted white to show their solidarity with the victim (the word "blanco" means "white" in Castilian).
} 
for human rights, democracy and tolerance in the Basque Country." 28 One of the initiatives of the organization prepared by Savater's wife in which he also participated was the trip of the "bus of liberty" which started in San Sebastián and ended in Cádiz. The activists were stopping in selected Spanish cities to organise meetings and distribute leaflets to raise awareness of the situation of the Basque Country. ${ }^{29}$

In the last years, Savater also supported the organization Colectivo de Victimas del Terrorismo (COVITE) fighting terrorism "with words". ${ }^{30}$ Its activity concentrates on three basic areas, which are: activism, dialogue and investigation. The Basque philosopher was a guest speaker during COVITE's annual 13th conference, and in 2018 he was granted their XVII Premio Internacional for "his civic engagements and his constructive fight against radicalisms and for freedom." 31

\section{Politics}

After few years ¡Basta Ya! started to lose momentum. Therefore, its leaders with Savater among them decided to create a political party to proceed with their postulates. In 2007 Union, Progress and Democracy (UPyD) was founded. The Basque philosopher was never its member, but he was its intellectual leader. ${ }^{32}$

The new political party was a transverse project that aimed to form a "third way" on the Spanish political stage. Its founders wanted to break the traditional division between the right and the left wing to give voters an alternative to choosing between PP (People's Party) and PSOE (Spanish Socialist Workers' Party).

The main idea defended by UPyD was to reform Spain the way it would become a strong, multicultural state. The main proposals were the following: secularism, European federalism, fiscal reform and fight against corruption, defence of state unity by reinforcing the role of Castilian in a more homogenous educational system, reaffirmation of social and labour security.

In 2008 and 2011 the party managed to introduce representatives in Cortes Generales. Also in the 2009 and 2014 elections to the European Parliament, some of its members gained the seats. However, since 2014 the formation had been experiencing some crisis, which was deepening more and more. One reason being the despotic way of managing the party by its co-founder Rosa Díez, another the internal conflicts.

Fernando Savater was one of the first among UPyD supporters who suggested that a union with Cs (Ciudadanos, Citizens) would be a good move. Regardless,

28 The Sakharov Prize, European Parliament, ¡Basta Ya! — 2000, Spain, https://www.europarl.europa.eu/sakharovprize/en/-basta-ya-2000-spain/products-details/20200331CAN54182 (accessed: 10.05. 2021).

${ }^{29}$ Cf. F. Savater, La peor parte. Memorias de amor, Barcelona 2019, pp. 200-202.

${ }^{30}$ COVITE, Quiénes somos, https://covite.org/nosotros/quienes-somos/ (accessed: 10.05.2021).

${ }^{31}$ COVITE, COVITE concede su XVII Premio Internacional al filósofo y activista Fernando Savater, https://covite.org/destacada/covite-concede-su-xvii-premio-internacional-al-filosofo-y-activis ta-fernando-savater/ (accessed: 10.05.2021).

32 The party also had support of the writer and Nobel Prize winner Mario Vargas Llosa. 
Díez rejected the idea highlighting the importance of the independence of UPyD's project.

Due to not winning any seat in the general elections since 2015, the party was dissolved in December 2020.

In 2019 Fernando Savater was pronounced to be a Citizens' candidate in the European Parliament election. ${ }^{33}$ His name was the last on the candidate list. What motivated the philosopher to become a candidate was rather to support other ex-UPyD members who ran from the same list. After all, Savater has always shared his political affinity rejecting membership of any party.

The agenda of UPyD seemed to work almost perfectly with the vision of state he has had for decades. Despite his liberal approach when it comes to moral issues, Savater feels an increasing reservation about voting for socialists. Apart from populism, his main accusation is their constant collaboration with nationalist parties, although he realises those alliances are most frequently formed with the intention to gain a parliamentary majority.

Recently, the philosopher surprised public opinion with his declaration of voting for the first time in his life for the People's Party in this year's Madrilenian regional election. ${ }^{34}$

\section{Anti-nationalism}

In his biography, Savater openly admits sympathizing with the Basque nationalist movement in the 1970s. He confesses taking part in Herri Batasuna meetings and collaborating with the newspaper Egin. "I5 even put an ikurriña at the entrance of my flat in Madrid!" 36 he wrote. However, as he explains in the next sentence: "It seemed to be the best way to recover Spanish democracy." 37

In the prologue of one of his most important and appreciated books, La tarea del héroe, written in 1981 he stated: "The struggle for dignity and recognition of the Basque nation in which I have the honour to participate, though from a distance of an erudite, seems to be one of the most ethically encouraging matters of democratic Spain." 38

Recently the philosopher acknowledged the fact that most people felt some appreciation for separatist movements for their "anti-Francoist pedigree" 39 and that this was his case as well. What is most important in the end is that Savater

\footnotetext{
33 Cf. Agencia Europa Press, 'El filósofo Fernando Savater cierra la candidatura de Ciudadanos a las elecciones europeas,' elDiario.es 24.04.2019, https://www.eldiario.es/politica/fernando-savater-candidatura-ciudadanos-elecciones_1_1583819.html (accessed: 10.05.2021).

${ }^{34}$ Cf. F. Savater, 'Convencido,' El País 24.04.2021, https://elpais.com/opinion/2021-04-24/con vencido.html?event_log=go\&prod $=$ REG\&o=CABEP (accessed: 10.05.2021).

${ }^{35}$ Cf. F. Savater, Mira por dónde, p. 362.

36 Ibidem.

37 Ibidem.

${ }^{38}$ F. Savater, La Tarea del héroe, pp. 18-19.

${ }^{39}$ F. Savater, La peor parte, p. 184.
} 
concluded that radical peripheral nationalism will share pornography's fate. ${ }^{40} \mathrm{He}$ thought that regional patriotism and ETA attacks grew stronger in the first years after the democratic transition since it was strictly forbidden to express a local identity for nearly four decades. In his understanding if something stops being prohibited, it stops being interesting, therefore, he was expecting the number of attacks to diminish with time. "I was wrong," ${ }^{11}$ he admits.

In 1984 the book Contra las patrias was published, which is a compilation of Savater's first articles dedicated to the criticism of nationalism. One of its main thoughts is that "nationalism is one of the worst political diseases of our century." ${ }^{2}$ In the preface to the second edition of the book, which was released twelve years later, the author explains his ambivalence towards the reissue. On the one hand, he acknowledges feeling a sort of satisfaction in the face of the demand for the book. On the other hand, though, he considers that the need for discussing the same ydeas is clear proof of their practical inefficiency ${ }^{43} \mathrm{In}$ another book written in the mid-nineties, he expresses the following amazement:

The end of the 20th century is possessed by nationalism to a greater extent than its beginning. Precisely now, when one would say that the globalization of communications, the multinationality of large companies and the global nature of the most serious problems on the planet (overpopulation, ecological disorders, hunger, etc.) make a trend towards a cosmopolitan vision reasonably inevitable. ${ }^{44}$

Yet twenty years later the Basque thinker feels obliged to write yet another book on the subject - "a pamphlet" 45 as the author himself classifies it. That is Contra el separatismo containing articles analysing the socio-political situation of Spain, which was published in 2017.

The list of Savater's objections against nationalism is long. As the philosopher highlights, being part of a group gives an individual a sense of belonging, which is one of the basic human needs. Being recognised by others builds one's identity. At the same time, though, demand for confrontation appears. The group determines itself in opposition to others. The others, therefore, need to be defined as well as it is required to perceive them as worse or dangerous. In the opinion of the philosopher, heterophobia is a very human feeling, but an "atavistic mechanism" 46 at the same time. This is why, in reference to the present social reality, he calls it a "moral illness". ${ }^{47}$ For the more backward society is, the stronger the fear of others. However, "nationalism is not an emotion, but a political ideology"48 and institutionalization of violence is its essence. ${ }^{49}$

\footnotetext{
${ }^{40}$ Cf. F. Savater, Mira por dónde, p. 363.

${ }^{41}$ Ibidem, p. 364.

${ }^{42}$ F. Savater, Contra las patrias, Barcelona 2007, p. 59.

43 Cf. ibidem, p. 11.

${ }^{44}$ F. Savater, Diccionario filosófico, Barcelona 2007, loc. 5689.

${ }^{45}$ F. Savater, Contra el separatismo, Barcelona 2017, loc. 41.

${ }^{46}$ F. Savater, Diccionario filosófico, loc. 2196.

47 Ibidem.

${ }^{48}$ F. Savater, Contra las patrias, p. 197.

${ }^{49}$ Cf. ibidem, p. 30.
} 
The Basque philosopher maintains that all nationalism is based on two mythical dogmas: that "national reality" exists before the will of discovering it and that the right to political self-determination equals the possibility to found an independent state. ${ }^{50}$ Savater belongs to the group of thinkers who are convinced that it is nationalism that invents a nation and not the other way around. Thus, he does not hesitate to call nationalism theocratic.

Its religiousness is visible in the striving for uniformity. It is always strictly defined and settled who is or may be classified as a member of a given nation. Homogeneity of the group is also the greatest value and should be protected.

Nationalism is always focused on the past sustaining a "mythology of the origin" ${ }^{51}$ since the collective subject is more real and its purity cannot be questioned. The members of the group may have their flaws, but "the Group" is always perfect, determined and valuable. "Nobody knows what a 'Nation' (Pueblo) is, except for the ones who shout on its behalf. [...] The 'Nation' is a mythological category, loaded with nineteenth-century emotion which is more evaluative than descriptive. The 'Nation' is always good [... $]^{52 "}$, we read in one of the philosopher's recent books.

Since "the Nation" is by its definition noble, just and morally superior, it is common to put it in the role of a victim. Martyrology and nationalism go along very well. Therefore, not only the concept of nation is created in opposition to the concept of an enemy, but it is required of the enemy to stay present as a constant threat. It increases integrity and promotes cooperation, however, nowadays it may have an additional function. "Of course the majority of nationalists do not desire to complete the difficult journey of the independence as much as to threaten permanently with liberation from the country to gain profits [...]," ${ }^{153}$ sustains Savater.

Not only is then nationalism a big mystification, but it imposes a belief that the vision it promotes discovers the natural order of the reality when every human community is always artificial. ${ }^{54}$

Another great logical error, as the philosopher often highlights, is to treat regions or languages as collective subjects. Only individuals are subjects, therefore, only they have rights and obligations.

In the last decade, Savater focuses on the critique of separatism more than of nationalism since "nationalism as a collective narcissism might be mild and even amusing"55 whereas separatism is "a poisoned arrow which targeted the very centre of our national coexistence. ${ }^{156}$ Hence his objections regarding 1-O Catalan independence referendum of 2017. For the philosopher, enouncing such voting by itself means proclaiming independence. ${ }^{57}$ What is more, this political act gives the

\footnotetext{
${ }^{50}$ Cf. ibidem, p. 37.

51 Ibidem, p. 165.

${ }^{52}$ F. Savater, ¡No te prives! Defensa de la ciudadaní, Barcelona 2014, p. 94.

${ }^{53}$ F. Savater, Diccionario del ciudadano sin miedo a saber, Barcelona 2007, p. 44.

${ }^{54}$ Cf. ibidem, p. 42.

${ }^{55}$ F. Savater, Contra el separatismo, loc. 54 .

${ }^{56}$ Ibidem, loc. 46.

57 Cf. F. Savater, ¡No te prives!, p. 186.
} 
right to decide to a part of the society (the citizens of Catalonia) when the issue concerns the whole Spanish society. ${ }^{58}$

Already in the 1980s, Savater was expressing his indignation when it comes to the fight for national identity in a democratic society. "Perhaps someone is forbidden to speak their language or to get their children educated in it [...]? Is it prohibited to eat paella, ${ }^{59}$ dance muñeira ${ }^{60}$ or play txistu? ${ }^{61}$ Can't people celebrate their traditional holidays or invent new traditions ad libitum? Don't nationalists administrate culture and education in the respective autonomous communities? What are then the imaginary threats to this yet another delusion that is the national identity?"62 At the same time, he explains that "[t]o detest homelands and abominate nationalisms doesn't mean to reject the necessary solidarity with every social group and by no means condemn the esthetic charm of different customs, languages, rites and lifestyles. It also doesn't mean forgetting shared traditions [...]." ${ }^{\prime 63}$ This thought was best expressed by another Spanish philosopher, Julián Marías, frequently quoted by Savater in this context. For Marías the suffix "-ism" indicates the same phenomenon as "itis". "One can recognise himself as a member of a given nation not being a nationalist as he can have appendix not suffering from appendicitis..." 64

It is not that Fernando Savater denies or underestimates his roots. His intention is to oppose any oppression an individual may experience. He is against any top-down identity constructions as they consistently limit personal freedom. He is against building identities that highlight differences between people and determine or seek conflicts. He opposes irrational social regulations which result in exclusions of particular groups as well as to the promotion of historical myths thanks to which the law becomes restrictive to some citizens.

\section{Pro-democracy}

Despite putting a blank vote in the constitutional referendum of 1978, after a few years, Savater became a fervent supporter both of democracy and of the Spanish constitution itself. It was after the 1981 coup d'état attempt of the lieutenant colonel Antonio Tejero that the philosopher changed his political views or rather abandoned his apolitical attitude. As Marta Nogueroles Jové argues, if it had not been for the coup d'etat, Savater would probably stay on the margin of political life. ${ }^{65}$ It seems that this event made Spanish intellectuals realise that as imperfect as the young democracy was, losing it may pose a great danger to the whole society.

\footnotetext{
${ }^{58}$ Cf. F. Savater, Contra el separatismo, loc. 337.

59 Traditional dish from Valencia.

60 Traditional Galician dance.

${ }^{61}$ Basque flute.

${ }^{62}$ F. Savater, Contra las patrias, p. 198.

${ }^{63}$ Ibidem, p. 159.

${ }^{64}$ Ibidem, p. 198.

${ }^{65}$ Cf. M. Nogueroles Jové, Fernando Savater, p. 183.
} 
The decade of the 1980s is also characterised by the increasing role of an intellectual in the Spanish society, which was in decadence during the age of Franco. This is when "Fernando Savater becomes a paradigm of a committed intellectual." 66 His presence in the media is increasingly frequent and his opinions influence deeply the worldview of his compatriots. The philosopher accepted his role and recognised his responsibility in supporting democratic values which he keeps defending until today.

For he claims that there is only one "civilization" (in opposition to "cultures" which are many) ${ }^{67}$ to which we should aspire to belong. "Civilization is the effort to emphasize what human beings have in common [...]. [...] It does not annul cultural belonging of anyone, but, based on it, it proposes another, wider one which none territorial authority can manage." 68 At the same time, he stresses that the idea has a long history and that it has been developing for centuries. Recognising its revolutionary character, he declares his will to fight for it.

The concept of civilization contains the idea of humanity and democracy. No matter how individualistic Savater's ethics project is, he admits that "being a human is knowing precisely that one cannot be human on their own." ${ }^{\prime \prime 9}$ Of course, every person is raised in a specific culture, however, the basic experiences of life are understandable inter-culturally, which should encourage us to think about others from the perspective of humanity. "Referring to 'humanity' we allude to a symbolic purpose, a peculiar creative indeterminacy"70 and to "an internal and active ability to self-determination." "71 Humanity means, therefore, freedom and independence, but also responsibility and constant effort since it is endless. ${ }^{72}$

Defending individual freedom leads to the conclusion that the essence of democracy is to "accustom oneself to live in disconformity." "I It requires the application of such concepts as tolerance and secularity which consists in "separating citizenship from any pre-political conditioning." 74 Democracy is "a social order of equals" 75 where everyone has the same political and social rights accompanied by the same obligations in respecting the law. It is "a combination of rights, obligation and guarantees granted by the State to each one of us. They are not based on any cultural, ethnic, ideological, religious, racial predetermined identity, but in our belonging to an institution as its members [...]. [...] the maximum of personal freedom $[\ldots]^{p 76}$

\footnotetext{
66 Ibidem, 188.

${ }^{67}$ Cf. F. Savater, Diccionario filosófico, loc. 370.

68 Ibidem.

${ }^{69}$ Ibidem, loc. 1049.

70 Ibidem, loc. 5541.

${ }^{71}$ Ibidem, loc. 5573.

72 Cf. ibidem, loc. 5795.

73 Ibidem, loc. 1070

${ }^{74}$ F. Savater, iNo te prives!, p. 36. In this context Savater adds that he "fears that this is as wrongly understood in Europe as it is in Spain". Ibidem, p. 37.

${ }^{75}$ F. Savater, Diccionario del ciudadano sin miedo a saber, p. 9.

${ }^{76}$ F. Savater, ¡No te prives!, p. 10.
} 
In contrast to diversity which is a social fact, "equality is a social conquest" and our greatest "wealth." 77 The most important aspect of the democracy of the twenty-first century is for Savater undoubtedly what it avoids and not what it gives. ${ }^{78}$. Alluding to the situation in his own country, the philosopher often repeats that "there certainly is a right to be different [...], but it does not equal a difference of rights." $" 79$

Savater is not only preoccupied with the state of democracy of his homeland, but he also expresses his opinions on the future of the European Union. He postulates "the Europe of the citizens" instead of "the Europe of nations." ${ }^{\text {" }} 0$ He would like to see the European Union playing the role of a supranational institution with a constitution that would secure the basic rights of citizens of the member countries if the national governments were reluctant to do so. However, first, the reactionary groups of nationalists, separatists and European sceptics need to be defeated as they always focus on the past. "Meanwhile the progressive ideas require on the contrary, that our true roots are in the future." "Let us hope that Europe is seen as a necessity, a promise and a triumph shared by all the Europeans without the necessity of inventing any exterior enemy to achieve its unity" ${ }^{\prime \prime 2}$ the philosopher wrote in El País in May 2019 before the European Parliament elections.

The vision of democracy and citizenship held by Savater is, then, an ideal opposition to his idea of nationalism. Democracy is based on rational concepts, individualism, freedom and is related to the Enlightenment's humanistic approach. It focuses on the similarities of human beings and seeks peace. Unlike nationalism, it is including and emancipating.

\section{Between Unamuno and Ortega y Gasset}

Fernando Savater is in an intellectual debt to the great 20th century Spanish thinkers - Miguel de Unamuno and José Ortega y Gasset. What he shares with them are not only philosophical ideas but also the style of his writing and life attitude. The three thinkers, who mastered the essay, became respectful public figures involved in politics. Savater expressed his admiration for the works of his predecessors more than once, highlighting their importance not only for the Spanish cultural heritage but also for the European philosophical legacy. ${ }^{83}$

Unamuno was a precursor of existentialism, obsessed with the topic of immortality. He rejected abstract ideas and focused on a human being as an indi-

${ }^{77}$ F. Savater, Diccionario del ciudadano sin miedo a saber, p. 10.

78 Cf. F. Savater, Diccionario filosófico, loc. 1196.

${ }^{79}$ F. Savater, Diccionario del ciudadano sin miedo a saber, p. 11.

${ }^{80}$ F. Savater, 'La Europa necesaria,' El País 22.05.2019, https://elpais.com/elpais/2019/05/21/ opinion/1558452531_097857.html (accessed: 10.05.2021).

${ }^{81}$ F. Savater, iNo te prives!, p. 210.

${ }^{82}$ F. Savater, La Europa necesaria.

${ }^{83}$ Cf. F. Savater, El arte de ensayar. Pensadores imprescindibles del siglo XX, Barcelona 2009, p. 19-20, p. 87-102 and p. 35-37 or F. Savater, La aventura del pensamiento, Buenos Aires 2010, p. $287-298$ and p. $311-321$. 
vidual, emphasising the role of emotions and desires in one's life. He was a catholic who was rational enough to have his doubts regarding his faith, however, faithful enough to feel desperate to long for unconditional belief. Therefore, human life was considered by him as a constant fight between reason and madness. In his most famous book, The tragic sense of life, he expresses the idea that the true tragedy of human beings is that they do not want to die. Since Unamuno was a master of paradox, a polemic author, who was exploring the subject of the catholic faith, his books got included in Index Librorum Prohibitorum.

His thought is frequently compared to the philosophy of two decades younger Ortega y Gasset. Unlike Unamuno, he was an atheist and he was convinced Spain should take an example from Europe in shaping its sociopolitical life. In the beginning influenced by neo-kantian thought, soon he developed his own ideas such as perspectivism and ratiovitalism. The concepts of biography, generation, vocation and circumstances play a key role in his thought. In his perspective, human beings do not have nature, but history. Also, they are constantly developing, therefore, whole societies are able to improve as well (Regenerationism). In the final stage of his creativity, Ortega was emphasising the notion of life as the foundation of reason. His best known work is The revolt of the Masses, the sociological intuitions of which are still valid today.

The aspects of Unamuno's thought, which undoubtedly influenced Savater, are emotions treated as the essence of human existence, the concepts of desire, death and immortality. Like Unamuno and Ortega y Gasset, Savater cherishes individualism and freedom, however, he always considers them in the perspective of social life. In his ethics, he refers to life, reason and autonomy with a visible influence of Ortega. His thought is as asystematic and aphoristic as the way his predecessors expressed their ideas.

\section{Criticism}

The book Panfleto contra el Todo was quite a success, however, it was harshly criticised. José Luis Abellán declared that "it is clear that what Savater rejects is not the order of Dictatorship, but any Order," 84 and Ignacio Sotelo accused the author directly of being a fascist. ${ }^{85}$

Due to his opposition to ETA terrorism, he was treated as a centralist in the Basque Country. On the other hand, because of his criticism towards the activity of GAL, ${ }^{86}$ in the capital, he was seen as an ETA supporter and "a dangerous nationalist." ${ }^{87}$

Nevertheless, what aroused the most criticism around Savater was his philosophical and political turn in the 1980s, when he abandoned anarchism and be-

84 J.L. Abellán, Ortega y Gasset y los orígenes de la transición democrática, Madrid 2005, p. 280.

${ }^{85}$ Cf. M. Nogueroles Jové, Fernando Savater, p. 149.

${ }^{86}$ Grupos Antiterroristas de Liberación, Antiterrorist Liberation Groups - an illegal organization created unofficially by the socialist Spanish government with the aim to combat ETA.

${ }^{87}$ F. Savater, Mira por dónde, pp. 374-375. 
came a strong democracy supporter. Some claim that he was motivated more by personal than political reasons. ${ }^{88}$ The philosopher himself likes to quote Keynes while explaining his change of mind. When someone accused the economist of abandoning his ideas, he was replying: "Yes, indeed, when I think I am wrong, I change my opinion. What do you usually do in such a situation?"89 Savater believes that sustaining the same point of view throughout the years is a symptom of the lack of thinking and not of being true to oneself.

Being an enthusiastic supporter of individual freedom, the philosopher is also criticised for his attitude to such delicate matters as abortion, euthanasia and drugs legalization. After he revealed himself a defender of bullfighting, the animal rights supporters also came out against him.

\section{Conclusions}

Fernando Savater is a European thinker par excellence. He is not only a great erudite and connoisseur of Western culture but also its devoted promoter.

His biggest accomplishment as an ethicist is his consequence and effort in recovering the most valuable ideas that kept appearing in the history of philosophy and combining them into one reasonable vision. Being inspired by the idea of radical human freedom and autonomy, he assumed Nietzsche's critique of ancient moral systems and acknowledged the role of pleasure in ethics. Starting with the concept of Aristotle's practical excellence, he added to it Spinoza's anthropology supported by Enlightenment's humanism.

Savater's defence of democracy is well-established and his argumentation is clear, sober yet presented with a great dose of humour supported with practical examples. The evolution of his political thought is strictly linked with the historical changes experienced both by Spanish and European societies in the last five decades. In this context, the philosopher shares the attitude of his great predecessor, José Ortega y Gasset, who proclaimed radical dynamics of life. The way Savater emphasised the role and position of an individual in a society is, on the other hand, a continuation of María Zambrano's concept of person and democracy.

Savater's consequent and extremely critical approach to nationalism made him a social hero as he was the first Spanish intellectual openly calling ETA a terrorist organization. It is worth repeating that this position was, neither more nor less, life-threatening.

The analysis of his biography and historical events experienced by the whole Spanish society shows that they play a key role in understanding the postulates of his political philosophy. His thought is undoubtedly circumstantial. One may criticise the philosopher for his changes of opinion, however, it is not to be denied that they are always rational, sober and well argued. The socio-political situation is always present in his philosophical reasoning and in order to discover its deep sense, it is indispensable to apply the hermeneutic method.

${ }^{88}$ Cf. M. Grijalba Uche, El laicismo en el pensamiento de Fernando Savater, p. 296.

${ }^{89}$ F. Savater, La voluntad disculpada, Madrid 1996, p. 12. Quoted in: M. Grijalba Uche, El laicismo en el pensamiento de Fernando Savater, p. 29. 
Thanks to the lightness of his style of expression, the philosopher's writings and public appearances became opinion-forming very quickly. His books and comments inspired many to become significant actors on the Spanish democratic stage.

Savater's pro-civic attitude certainly is his hallmark, and the recognition he receives in Spanish society is to be admired or even envied. For there are just a few philosophers who exert such influence on public life. We could indicate Jürgen Habermas as one of them. When it comes to Polish reality, one may compare Jan Hartman or Magdalena Środa with Savater. However, they are hardly recognisable to the extent the Spanish philosopher is.

Fernando Savater spent his youth in a dictatorship country, which gained power after a horrifying civil war and reinforced it after a disastrous world war. He dedicated his whole life to educate his readers to avoid repeating history. In the last few years the European society faced deep divisions, and one may recall $20^{\text {th }}$ century Spain as one of the greatest examples not to follow. Savater's books provide more than enough arguments as to why it is so and those are his biggest contribution to contemporary political philosophy.

\section{References}

Abellán J.L., Ortega y Gasset y los orígenes de la transición democrática, Madrid 2005. Kuczyński M., Krwawiaca Europa, Warszawa 2001.

Llanos-Antczak A., Separatyzm baskijski: historia, wspótczesność, perspektywy, Warszawa 2019.

Nogueroles Jové M., Fernando Savater. Biografía intelectualn de un «joven filósofo», Madrid 2013.

Santayana G., The Complete Works of George Santayana, Shrine of Knowledge, Kindle Edition 2020.

Savater F., El arte de ensayar. Pensadores imprescindibles del siglo XX, Barcelona 2009.

Savater F., La aventura del pensamiento, Buenos Aires 2010.

Savater F., Las ciudades y los escritores, Barcelona 2013.

Savater F., El contenido de la felicidad, Madrid 2006.

Savater F., Contra las patrias, Barcelona 2007.

Savater F., Contra el separatismo, Barcelona 2017.

Savater F., Diccionario del ciudadano sin miedo a saber, Barcelona 2007.

Savater F., Diccionario filosófico, Barcelona 2007.

Savater F., La escuela de Platón, Barcelona 1991.

Savater F., Ética como amor propio, Barcelona 1988.

Savater F., Ética de urgencia, Barcelona 2012.

Savater F., Ética para la empresa, Barcelona 2014.

Savater F., Etyka dla syna, transl. J. Wojcieszak, Warszawa 1996.

Savater F., La filosofía tachada, Madrid 1972

Savater F., Historia de la filosofía. Sin temor ni temblor, Barcelona 2009.

Savater F., Idea de Nietzsche, Barcelona 1995

Savater F., Invitación a la ética, Barcelona 2005.

Savater F., Jorge Luis Borges: la ironía metafísica, Barcelona 2000. 
Savater F., Mira por dónde. Autobiografía razonada, Madrid 2005.

Savater F., ¡No te prives! Defensa de la ciudadanía, Barcelona 2014.

Savater F., Panfleto contra el todo, Barcelona 1978.

Savater F., Para la anarquía y otros enfrentamientos, Barcelona 1977.

Savater F., Pensar la vida. Ética para Amador. Política para Amador. Las preguntas de la vida, Barcelona 2016.

Savater F., La peor parte. Memorias de amor, Barcelona 2019.

Savater F., Las razones del antimilitarismo y otras razones, Barcelona 1984.

Savater F., La tarea del héroe, Barcelona 2004.

Savater F., Todo mi Cioran, Barcelona 2018.

Savater F., El valor de educar, Barcelona 1997.

Savater F., El valor de elegir, Barcelona 2003.

Savater F., Voltaire contra los fanáticos, Barcelona 2015.

Savater F., Martinez-Fresneda G., Teoría y presencia de la tortura en España, Madrid 1982.

Savater F., Torres S., Aqui viven leones, Barcelona 2015.

\section{Internet sources}

Agencia Europa Press, 'El filósofo Fernando Savater cierra la candidatura de Ciudadanos a las elecciones europeas,' elDiario.es 24.04.2019, https://www.eldiario. es/politica/fernando-savater-candidatura-ciudadanos-elecciones_1_1583819.html.

Ceberio Belaza M., 'El dolor por 854 muertos y miles de amenazados y heridos,' El País 4.05.2018, https://elpais.com/politica/2018/05/03/actualidad/1525374369_ 414522.html.

Colectivo de Víctimas del Terrorismo, https://covite.org.

Escriva A., 'El testamento de ETA: 864 asesinados "por amor",' El Mundo 28.04.2021, https://www.elmundo.es/cronica/2021/04/28/6082fd4cfc6c83651b8b45a3.html.

IE University, Hay Festival Segovia Fernando Savater y Adam Michnik. La lucha por Europa, 2020, https://www.youtube.com/watch?v=GYkAwRvF1Z0\&t=940s.

Gesto por la Paz, http://www.gesto.org/es/.

Grijalba Uche M., El laicismo en el pensamiento de Fernando Savater, 2016, http://espacio.uned.es/fez/eserv/tesisuned:Filosofia-Mgrijalba/GRIJALBA_UCHE_ Miguel_Tesis.pdf.

Ormazabal M., 'ETA anuncia su disolución', El Pais 3.05.2018, https://elpais.com/ politica/2018/05/03/actualidad/1525336524_523980.html.

Savater F., 'Convencido', El País 24.04.2021, https://elpais.com/opinion/2021-04-24/ convencido.html? event_log $=$ go\&prod $=\mathrm{REG} \& \mathrm{o}=\mathrm{CABEP}$.

Savater F., 'La Europa necesaria', El País 22.05.2019, https://elpais.com/elpais/2019/ 05/21/opinion/1558452531_097857.html.

The Sakharov Prize, European Parliament, iBasta Ya! - 2000, Spain, 2000, https:// www.europarl.europa.eu/sakharovprize/en/-basta-ya-2000-spain/productsdetails/20200331CAN54182.

Other sources

Savater F., Lugares con genio, DVD, Madrid 2011. 